\title{
Leadership Strategies of Elementary School Principals in Developing Teacher Professionalism
}

\author{
Irdayanti Mat Natsir ${ }^{1}$, Nunuk Hariyati ${ }^{2}$, Suyud ${ }^{3}$, Diani Fitriana Susmita ${ }^{3}$, Dwi Esti \\ Andriani $^{3}$ \\ ${ }^{1}$ Universiti Pendidikan Sultan Idris, Tanjong Malim, Perak, Malaysia \\ ${ }^{2}$ Universitas Negeri Surabaya, Surabaya, Jawa Timur, Indonesia \\ ${ }^{3}$ Universitas Negeri Yogyakarta, Yogyakarta, DIY, Indonesia
}

Corresponding author: Dwi Esti Andriani (e-mail: dwi_esti@uny.ac.id)

\begin{abstract}
Principal leadership plays a vital role in school effectiveness through its direct effect on teachers. This study aimed to explore the leadership strategies performed by school principals to develop teacher professionalism at elementary schools. The theoretical underpinnings of interpretivism guided this study. It employed in-depth semistructured interviews and document analysis to collect data. The interviews were conducted with nine elementary school principals in Klaten district, Indonesia. Data were analyzed using the grounded theory data analysis method, specifically the use of constant comparison through open coding. The 'open-coded' data were then analyzed using the analytic induction technique. The results show that the principals employ a wide range of leadership strategies to develop teacher professionalism. The strategies include providing exemplary behavior and attitude, fostering work discipline, motivating teachers, providing educational supervision, and encouraging teachers to participate in continuing professional development programs.
\end{abstract}

Keywords: principal leadership, teacher professionalism, teacher professional development

\section{Strategi Kepemimpinan Kepala Sekolah Dasar dalam Mengembangkan Profesionalisme Guru}

\begin{abstract}
Abstrak: Kepemimpinan kepala sekolah berperan penting bagi keefektifan sekolah melalui pengaruh langsungnya terhadap guru. Penelitian ini bertujuan untuk mengeksplorasi strategi kepemimpinan yang dilakukan oleh kepala sekolah untuk mengembangkan profesionalisme guru sekolah dasar. Penelitian ini menggunakan paradigma interpretivisme. Teknik pengumpulan data menggunakan wawancara semiterstruktur dan mendalam dan analisis dokumen. Wawancara melibatkan sembilan kepala sekolah dasar negeri di Kabupaten Klaten, Indonesia. Data wawancara dianalisis menggunakan metode analisis data grounded theory, khususnya teknik perbandingan konstan melalui open coding yang dilanjutkan dengan induksi analitis. Hasil penelitian menunjukkan bahwa kepala sekolah menerapkan beragam strategi untuk meningkatkan profesionalisme guru. Strategi tersebut meliputi: memberikan keteladanan sikap dan perilaku, membentuk kedisiplinan kerja, memberikan motivasi kerja, melaksanakan
\end{abstract}


supervisi pendidikan, dan mendorong guru untuk berpartisipasi dalam program pengembangan profesional guru berkelanjutan.

Kata kunci: kepemimpinan kepala sekolah, profesionalisme guru, pengembangan profesionalisme guru

\section{INTRODUCTION}

Teachers are one of the key components that affect the quality of education. Education will have a problem to succeed without professional teachers (Buchari, 2009). Ambarita (2015) states that professional teachers are those qualified in conducting their duties. They understand their duties well, have the willingness to work effectively with students, teachers, parents, and the community, develop visions and continuous growth of positions, prioritize service in assignments, direct, build and develop student behavior, and implement code of ethics of their profession (Rebore, 1991).

The reality of professional teachers in Indonesia, however, is still far from expectations. The 2016 UNESCO report shows that the quality of teachers in this country ranked 14th out of 14 developing countries in the world. This low quality of teachers accounts for the condition that $25 \%$ of the 3.9 total number of teachers have not met the academic qualification requirements, $63.1 \%$ have no undergraduate education, the significant number of teachers who have no professional certificates, less competence and lack of professional training ("Memprihatinkan potret pendidikan", 2018). Thus, it is not surprising that teacher professionalism remains an issue in the national education system.

Teacher professionalism can be defined as the degree of work or performance of teachers in carrying out their work or profession (Suparmin, 2015). This can be seen from the teacher's commitment to providing the best educational services for students (Suyanto, 2013) which have a direct effect on the learning process and outcomes. High professionalism requires continuous development efforts or programs (Ambarita, 2015).

The development of teacher professionalism is one of the duties and responsibilities of school principals (Daryanto, 2008: 80). Various results of school leadership research indicate that successful principal leadership needs to develop their staff (Harris, 2010; Jacobson, 2011; Leithwood, Harris, \& Hopkins, 2008; Ylimaki, Jacobson, \& Drysdale, 2008). This study, accordingly, aims to gain an understanding of staff development carried out by the principal in Indonesian public elementary schools. This research focuses on teacher development, more specifically, on leadership strategies 
that principals consider necessary and do to develop teacher professionalism in their schools.

\subsection{Teacher professionalism}

Professionalism is a notion which demands that every occupation must be performed by a professional (Nurfuadi, 2012), i.e. someone whose job requires a certain set of skills (Siswoyo, 2013), instead of a job done during the leisure time or hobbies (Herawati, 2009). Professionals are committed to always realizing and enhancing their professionalism through various methods and strategies in accordance with the demands of the current times and their profession so that their existence always gives a professional meaning (Mudlofir, 2013; Dharma, 2005: 67). Thus, professionalism can also be interpreted as the degree of achievement or performance of an individual in carrying out a job or profession (Suparmin, 2015: 11).

Professionalism is very important. Teacher professionalism will lead to the best attitude of a teacher in serving the educational needs of students that are useful for parents, the community, and the school where the teacher works (Suyanto, 2013). Teacher professionalism is formed by internal factors, namely talent, and interest, as well as external factors such as education and training, work facilities and infrastructure, and teacher welfare (Fathurrohman, 2012).

\subsection{Teacher professional development}

Teacher professionalism development refers to the activities carried out to enhance professional career growth (Aedi, 2014: 345). Activities undertaken include personal development, further education, in-service education, curriculum development, collaboration with colleagues, training, and mentoring with colleagues. A broader view of teacher professional development was expressed by Fullan in Aedi (2014: 345) who stated that professional development refers to several formal and non-formal learning experiences throughout one's career from pre-service education to retirement.

According to the definition, the development of teacher professionalism can be done by providing educational supervision, namely professional assistance to teachers in the effort to achieve the objectives of education (Purwanto, 2014: 76). It can be done by providing encouragement, guidance, and opportunities to develop expertise and skills. 
Providing examples of good teaching practices guide teachers in the innovation of education and teaching, selecting the appropriate learning tools and teaching methods and conducting systematic and comprehensive learning assessments (Purwanto, 2014). Depending on the needs, supervision can be focused on non-teaching related activities or works directly related to learning improvement. Supervision can also be focused on the weaknesses or problems faced by teachers in doing their job that need improvements. This is commonly called clinical supervision (Purwanto, 2014).

Educational supervision can also be done through mentoring. Mentoring suggests the development of effective communication relationships between mentors or supervisors in the process of developing teacher competencies (Hariwung in Aedi, 2014). Effective mentoring requires planning, implementation, evaluation, and follow-up (Muslim, 2010). The planning stage is needed to build trust in the relationship, as well as to exchange information, and set shared goals for the supervisors and teachers. The implementation phase is a work process for achieving mutual supervision goals. The evaluation phase is the process of evaluating the implementation of supervision and following up on the supervision objectives that have not been achieved (Muslim, 2010).

Teacher professionalism development can also be done through various forms of teacher competency improvement activities. Regarding this, Saud (2009) suggests the provision of further study opportunities to improve educational qualifications, equalization or certification, access to read and write journal articles or scientific works, the ability to conduct research (especially classroom action research), and internships or collaborations with colleagues (Saud, 2009). This view was shared by Aedi (2014) on how discussions on education issues, workshops, seminars, writing books or teaching materials, making learning media, and encouraging teacher activity in the Teacher Working Group (KKG) are all acceptable activities that can increase teacher professionalism.

\subsection{Principal leadership strategies in teacher professional development}

Leadership is a key factor that contributes to school effectiveness. Previous studies show that school leadership is the second factor only after teachers (Collins, 2001; Leithwood, Harris, \& Hopkins, 2008) which significantly influences student learning processes and outcomes (Collins, 2001; Karadag ־ Bektas, C,og altay, Yalem, 2015; Sun \& Leithwood, 
2015). In no case can a school succeed in increasing the performance of its students without the presence of talented leadership. Leadership works as a catalyst that unleashes the potential capacity in the organization (Collins, 2001; Leithwood, et al., 2008).

Recent studies identify four effective school leadership practices. The four intended leadership practices include: building a vision and setting direction, understanding and developing people or staff, redesigning the organization, as well as managing teaching and learning programs (Leithwood \& Riehl, 2003; Leithwood, et al., 2008). In addition, the results of the study show that school leadership practices are influenced by context. For example, large schools with a high diversity of community culture can hinder the ability of principals to design organizations or communicate with the community (Ylimaki, et al., 2008).

Staff development is one of the effective school leadership practices (Harris, 2010; Jacobson, 2011). The main objective is to build not only the knowledge and skills needed by teachers and staff to achieve organizational goals, but also their commitment, capacity, and resilience to continue applying knowledge and skills (Leithwood, Harris, \& Hopkins, 2008). For this reason, the leadership actions that need to be done are to assist and provide individual and collective support, intellectual stimulation, and an example or model of expected values and behavior.

The teacher is one of the main targets for staff development in the school. The main goal is high-level teacher professionalism. Related to this, Ambarita (2015) revealed the need of exemplary principals. She pointed out that the principal, as a leader, must be able to set an example of attitudes and behavior for school members, including teachers. An example of this exemplary behavior or attitude is coming early to school before the students or teachers arrive. The expectation of doing it is that teachers will feel ashamed or reluctant to arrive late to respect their principal. The principal also needs to monitor teaching from class to class to ensure that the learning process runs smoothly. If the teacher is not available to teach, the principal will teach the class. A good principal not only encourages communication among members of the school community but also demands respect and authority. Moreover, the principal must not be hesitant in maintaining the school's cleanliness, for example, by picking up litter (Daryanto, 2008: 102). 
The principal also needs to motivate teachers to work professionally, which is essentially transforming motivation into actions to meet the needs and achieve goals (Usman, 2002). This action expects that the teachers will be willing to carry out their duties with full awareness, responsibility and be open to various inputs and also new things (Ambarita, 2015). Sobri, Jihad dan Rochman (2009) revealed three motivating models as follows.

1. Traditional model, i.e. giving material incentives to high-performing employees

2. Interpersonal relation model, i.e. recognizing that all employees' social needs and making them feel appreciated

3. Human resource model, i.e. motivating employees with not only money but also the need for achievement that relates to responsibility

He further views that motivating teachers can be fostered through the management of the physical environment, working atmosphere, discipline, encouragement, and effective appreciation, as well as the provision of various learning resources through the development of Learning Resource Centers (PSB). Concerning effective appreciation, Marno (2012) points out the importance of linking them with work performance and teacher welfare. The improvement of teacher welfare can be done, among others, by providing incentives beyond salaries, rewards, appreciation, and work allowances (Mulyasa, 2006).

\section{METHOD}

This is a qualitative study with an interpretivism paradigm because it requires a research method that allows researchers to interpret social phenomena (O 'Donoghue, 2007). The theoretical framework used was the main theoretical framework in qualitative research, namely symbolic interactionism (IS) (O 'Donoghue, 2007). The IS approach focuses on how individuals interpret an object and other people in their world and how the interpretation process leads to the individual's behavior in a specific situation (Benzies \& Allen, 2001: 544).

This research was conducted in public elementary schools in Klaten Regency, Central Java, Indonesia. The study was conducted for two months. It also interviewed nine school principals in studied schools, using an in-depth semi-structured interview technique. During the interviews, the researcher listened carefully and noted what were 
stated by the informant (Sugiyono, 2015). A document study was used as a complement as well as data triangulation. Related documents analyzed include the plan and implementation of supervision programs, supervision notes, teacher attendance, curriculum documents, and others that are relevant.

The research instrument used was an interview guideline. Interview questions were developed based on the interpretivism paradigm with an IS theoretical framework. These questions were not specific questions to be answered, but rather a list of general questions with great potential to produce data related to the area of the research focus. These general questions were then broken down into a more specific set of questions to guide the interview. The following are examples of developing the general question into more specific questions.

Table 1. Interview Guideline

\begin{tabular}{llll}
\hline No. & Research Question & Guideline \\
\hline 1. & $\begin{array}{l}\text { What are the elementary school } \\
\text { principals' strategies that are deemed } \\
\text { necessary to develop teacher } \\
\text { professionalism at school? }\end{array}$ & $\begin{array}{l}\text { What leadership strategies have you done to } \\
\text { develop teacher professionalism at school? }\end{array}$ \\
& 1.2 & $\begin{array}{l}\text { Why do you choose that particular strategy? } \\
\text { Are there any supporting or inhibiting } \\
\text { factors that affect the implementation of the }\end{array}$ \\
& $1.3 \quad \begin{array}{l}\text { leadership strategies? } \\
\text { What do you expect from the leadership } \\
\text { strategies that you apply for the teachers at } \\
\text { your school? }\end{array}$ \\
& 1.4 & $\begin{array}{l}\text { Will participating teachers in various } \\
\text { activities such as seminars, workshops, and } \\
\text { training improve the quality of the school? }\end{array}$ \\
& &
\end{tabular}

The questions above served as preliminary questions that were believed to have the potential to lead researchers to further important questions needed to address research questions. In other words, these questions could develop flexibly in the field. In addition, in this case, the researchers also acted as the research instruments. According to Sugiyono (2015: 92), researchers are the main instruments in collecting data in the field of qualitative research.

The collected data were then analyzed using qualitative grounded theory data analysis technique, specifically open coding, through constant comparison by comparing similarities and differences between data and questioning the meaning of the data. The next stage of data analysis used the inductive analytic techniques. Table 2 below is an example of open coding. 
For the validity of the data, this study used technical triangulation, in which the credibility of the data obtained by researchers from the interview was examined using document studies.

Table 2. Open Coding Example

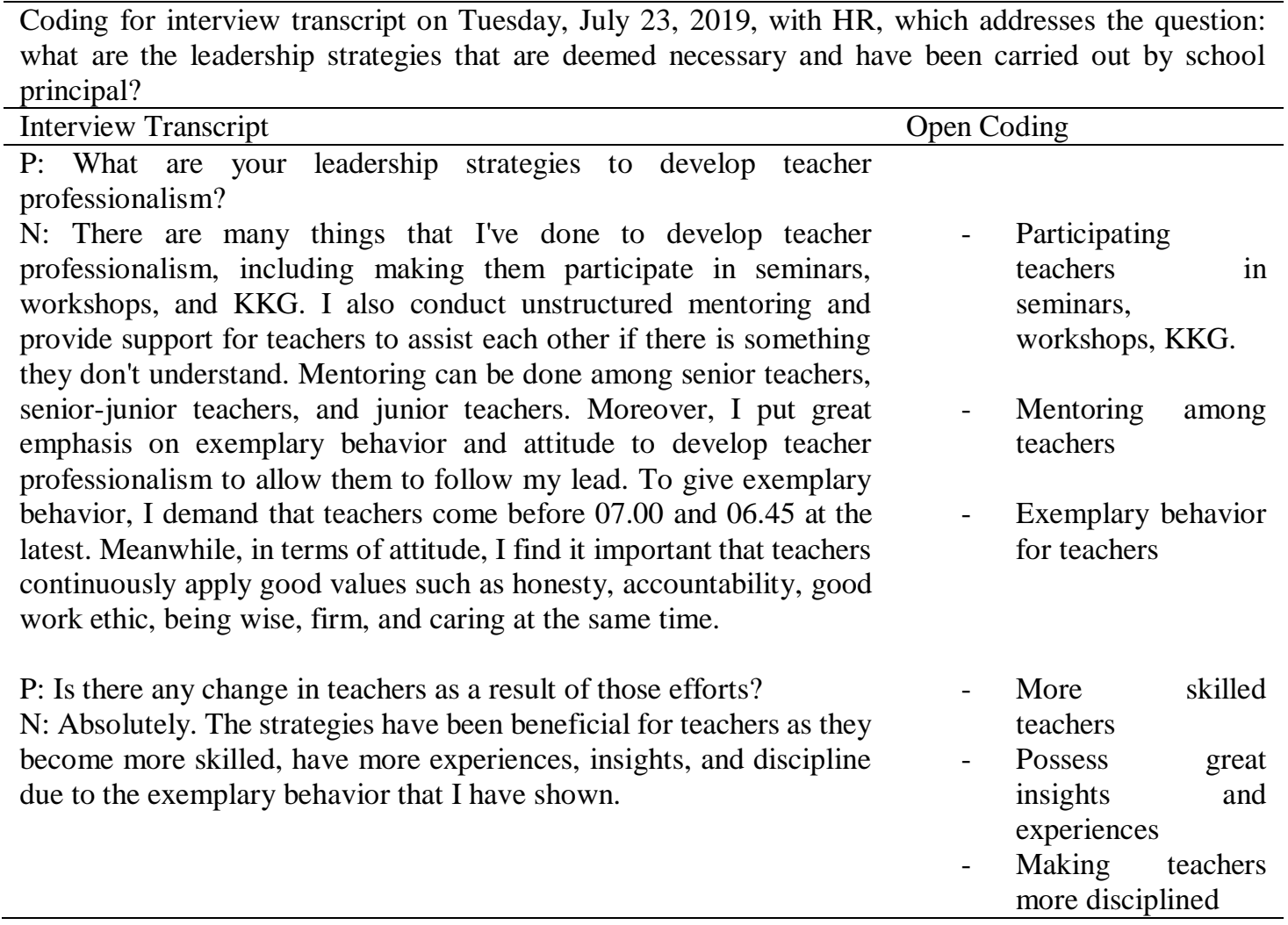

\section{RESULTS}

The research findings show that elementary school principals use a wide range of leadership strategies to improve the professionalism of teachers in their schools. This strategy includes providing exemplary behavior and attitude, disciplining work, motivating teachers, conducting educational supervision, and encouraging teachers to participate in continuing professional development programs.

\subsection{Providing exemplary behavior and attitudes}

Principals who participated in this study agreed that they must serve as role models for the teachers. Therefore, they must show exemplary behavior and attitude, which are ensured to improve teacher professionalism, especially in the aspects of personality and behavior. 


\subsubsection{Exemplary behavior}

The principals involved in this study perceived exemplary behavior to be instrumental in developing expected teacher behaviors. One of the examples of this behavior is to arrive early at school at 07.00 in the morning to develop discipline behavior among the school community. Once the principal arrives at school, he or she immediately greets the arriving teachers and students. One principal stated the following.

What I do to encourage teachers to come no more than 07.00 is to come even earlier than they do. This will make them embarrassed to come late, and hence, reduce the number of late teachers (HR-011)

A similar notion was also expressed by another principal, as follows.

I come early before the teachers come. Usually, I get to school at 06.40 at the latest, sometimes at 06.30. Coming early is not an issue for me as I have done all my chores. I want to be an example for others so that they don't come late. (KAR-011)

The principal believed that teachers should arrive early. Teachers can greet the students, guardians of students, or teachers who have arrived. This will increase the positive aura, which may initiate the beginning of a good spirit to start the work. Teachers' preparation for teaching will be better, as well, as they are not in a hurry and can come to the class on time. When they arrive at school right when the bell rings, this means that they still need more time to prepare their learning material. As a result, the teacher comes late and cause learning to be not optimal.

\subsubsection{Exemplary attitudes}

Principals believed that they must also provide exemplary attitudes to their teachers. It is hoped that the teacher will have the same attitude as expected by his profession. Principals viewed that exemplary attitudes must be practiced in their daily lives both inside and outside of school. These attitudes include being wise, fair, firm, pious, patient, understanding, friendly and merciful. One school principal revealed this:

I give an example not by words, but through my work attitude. For instance, when I lead a meeting, I would be strict, wise, fair, and open to all opinions. This helps teachers to be more aware of the values and learn to act in the ways that are expected by the school and their profession. (ED-012).

Another principal put emphasis on the importance of being friendly and open for teachers: 
I always stress the importance of being friendly and open to my teachers. (SRM012).

The above situation shows that the principal wants teachers to have good behavior and attitudes. They try to build teachers who are humanist, well-mannered, ethical and possessing a good moral. The strategy is by providing exemplary attitudes in everyday life.

\subsection{Fostering work discipline}

The principals expressed their concerns on the importance of work discipline as a part of teacher professionalism. Some of the aspects they considered to be important include the administrative and attendance record. These two aspects are further described below.

\subsubsection{Fostering administrative work discipline}

The principal revealed that they instill administrative discipline in the teacher. This discipline is related to teacher order in doing administrative work, especially curriculum administration such as developing Semester Program (SP), Annual Program (AP), and Lesson Plan (RPP). Teachers are required to try to finish this work on time. They consider teacher discipline in work important because of its great benefits for teachers. Order making promissory notes, for example, will facilitate the teacher in carrying out learning for one semester, provide direction for activities to achieve learning objectives, be a work guide for both teachers and students, be a benchmark of accuracy and inaction of work to save energy, time, tools and cost. According to a school principal:

I have always reminded the teaching staff to be consistent in doing the administrative work related to teaching, such as SP. This is important as it directly relates to the teaching process. (SW-021).

Another principal expressed similar points.

I always stress the importance of doing the administrative works among teachers, particularly the lesson plan, SP, and AP, which I personally make sure myself. While AP is concerned with the learning process in one academic year, SP is the learning in one semester (WR-021).

Another principal expressed similar points as he also emphasized building the teachers' discipline in completing the administrative work. 
Teachers need to be orderly in doing administration. I always ask the teacher to be orderly to do the work. I do check and assist them to minimize mistakes. (HR022).

Furthermore, the principals revealed that they also required their teachers to be orderly in doing class administration such as making a journal, filling in the list of student attendances every day, and checking student work. Although most teachers have been orderly in completing the administrative work, the principals said that they keep on monitoring the teachers' work.

This situation shows that the principal views administrative work is crucial since it is related to the learning process. Thus, he tries to make the teachers do administrative work orderly. He checks, supervises, guides and assists in order to make sure that the teachers work well and orderly.

\subsubsection{Monitoring time discipline}

The principals believed that discipline is a form of adherence to the rules set in schools. Discipline is an attitude and behavior shown because someone can put himself well in every situation and has awareness and willingness to live orderly and neatly. According to the principals, one of the disciplinary behaviors deemed important, as part of teacher professionalism is time discipline. They believed that the discipline teachers are those coming to work and coming home on time. Besides, the teachers need to work under the office hour by never leaving school without permission or doing personal business during teaching hours. It is essential since it directly affects the learning process and outcome.

Time discipline behavior of teachers is developed in several ways. As mentioned previously, the principals provided a model of disciplinary behavior and conducted direct monitoring to find out who arrived on time or late, and who went home on time or earlier. During the interview, the principals also revealed that they imposed regulations that anyone who needed to leave school or class during working hours must ask permission. Furthermore, they showed a selective attitude and decisiveness in making decisions whether or not permitted the teachers who requested to leave early. One of the school principals said:

Female teachers here often asked permission to go out to buy foods and side dishes, usually at 10 o'clock. I am being strict. I do not allow them. They change 
now. There are no longer teachers going out at 10 a.m. only to buy foods and side dishes. They do it after returning home after teaching (HR-022)

He further said that professional teachers are those prioritizing their students over personal matters. Thus, they should not leave the class or come late.

Another principal shows the strategy that he does to make the teachers more discipline in terms of time. He said that.

I monitor our teachers' arrival and departure time, so I know those who are being on time or late...(KAR-022)

It is assumed that the principal believes that professional teachers have the time discipline. Therefore, they see the need to set an example and be assertive in this regard.

\subsection{Motivating teachers to work professionally}

The principals stated that they motivate the teachers to work professionally. They did it by instilling religious values at work and conducting regular briefings before teaching. Both strategies are explained as follows.

\subsubsection{Instilling religious values at work}

The principals stated that they often motivate the teachers by reminding that teaching is not merely transferring knowledge, but it is a form of religious observance. One of the principals said:

Sometimes some teachers complain when facing an unruly child. Then I ask them always to remember that every effort takes time. Educating the students has become our shared responsibility, so do not complain, and then I reaffirm that it is religious observance. (SRM-031)

Moreover, another principal mentioned.

I remind teachers to sincerely work to get the reward and bless from Allah SWT. (ED-031)

The principals said that religious values are instilled in various forums, both formal and non-formal, such as in meetings and during breaks when talking with other teachers. They believed that religious values minimize the number of teacher's complaints when they are tired of teaching because the values are encouraging. 


\subsubsection{Regular morning briefing}

The principals stated that they conduct briefings every morning for five to ten minutes before the classes start. It aims to improve their motivation in working. Generally, in the briefings, the principals deliver encouraging messages, convey problems and difficulties in teaching, and respond to teachers' problems. A principal said:

During the briefing, what I say is none other than what motivates the teachers. In today's morning briefing, there was also a question and answer session between the teachers and me. This is important to review whether there are difficulties experienced by the teacher when teaching. (WR-031).

Similarly, other principal states:

The briefing can encourage and stimulate teachers so that they become more enthusiastic before teaching. Thus, regular morning briefing is useful. (IY-031).

This shows that briefing is considered important in motivating teachers to perform better.

\subsection{Providing educational supervision}

The school principals stated that they supervise the teaching practices of their teachers. They believed that supervision is important to help teachers overcome difficulties or problems related to their works. Supervision is carried out in the classroom visit and observation, as well as mentoring. The focus of supervision is on matters relating to academics, administrative or managerial works of teachers. The activities commonly done in educational supervision are explained as follows.

\subsubsection{Classroom visit and observation}

The principals stated that they conduct educational supervision by visiting the classroom and observing teaching practices. The classroom observation focuses on teaching techniques, the use of learning equipment, and assessment methods used to measure students' learning achievement. A principal stating supports this:

I visit the class once or twice a week by observing teachers in teaching-learning processes in the class. (KAR.041)

Another principal explained what the class visits mostly focused on.

When I observe the class, I try to observe whether the teachers can implement certain learning methods, instead of being monotonous. They can avoid using 
the lecture method and invite the students to discuss with one another to improve their enthusiasm. (HAR.042)

This situation shows that principals make sure that teachers can teach well and professionally. Moreover, they assist teachers who have difficulties with administrative work.

\subsubsection{Mentoring}

The principals stated that they promote mentoring in their schools. Senior teachers can do mentoring to junior teachers, or between the principal and teachers. It aims to improve teachers' competence. Moreover, the principals stated that mentoring focusing on curricula, teaching, and information technology is very often. This mentoring is considered important to foster mutual assistance between one teacher and another as well as to explain theories or practices that are not yet understood by teachers, for example, making a semester and annual program with different templates as required due to national curriculum changes. One of the principals conducted mentoring in information technology and noted the following points.

Junior teachers teach the senior teachers how to use the computer, although it is not scheduled mentoring. (IY-042)

It is in line with the other principal argument stating this:

I am not yet skillful to work on the computer, so I need supervision from junior teachers who master Information Technology. (IY-042).

He further stated that mentoring is important because IT training from the government is usually very few. Thus, mentoring can be the best solution. The school principals viewed that if teachers master IT, they can work more efficiently and independently in completing curriculum administration such as Semester Program (SP) and Annual Program (AP). This independence is one of the characteristics of professional teachers.

\subsubsection{Individual and informal supervision}

The principals also stated that they individually supervise the teachers who need it. They said that sometimes the teachers find difficulties in teaching or lack motivation in working. When the teachers are in this situation, the principals listen to their complaints 
and problems before providing advice, motivation, guidance, and solutions. One of the school principals said:

Sometimes I see teachers lacking enthusiasm at work. Usually, I would call them, and we would talk. I motivated and encouraged them... or if they had problems, I would try to help. (SW-043).

The other principal states that individual guidance that he provides to their teachers is on teaching skills. The principal says:

Once I saw a teacher delivering a lesson in a very low voice, and some students did not hear his voice clearly. When he was in the office, I talked to him and told him to talk more loudly to attract student attention. (SRM-043)

Doing this, principals, as they believed, can improve their teachers' teaching skills.

\subsection{Encouraging teachers to participate in continuing professional development programs}

The principals stated that teachers need to develop their professionalism continuously. Without professionalism, their knowledge and skills may no longer match the demands of the era. Therefore, the principals urge teachers to take part in workshops or training and encourage them to actively participate in Teacher Working Group programs held regularly in the local area and the non-regular ones. Below is an explanation about both programs.

\subsubsection{Teachers' participation in workshops and training}

The principals stated that there are workshops or conventions in education conducted every three months. They are enthusiastic in sending teachers to seminars or workshops although the number of teachers allowed to participate in such programs is determined by the Education Board (one teacher for each school). One of the principals mentioned this:

Every time there is a seminar, workshop, and training, I asked some teachers to participate, although the number is limited. (ED-051)

They said that when joining the activity, the teacher's knowledge and insight development. More principal noted that:

I am very enthusiastic about involving teachers in seminars and workshops. Nevertheless, you have to wait 3 or 4 months. After participating in the teacher professional development programs, their knowledge will improve so that we can share with others later. (IY-052) 
The situation shows that the principals always ask teachers to take part in workshops and training activities if there is an opportunity.

\subsubsection{Teacher participation in teacher working group/KKG}

The school principals stated that they encourage their teachers to be active in the local area $\mathrm{KKG}$ activities. The local area $\mathrm{KKG}$ is a program conducted regularly on Saturdays, once a week. The participation of teachers in the local area KKG is important for the development of their professionalism. KKG provide an opportunity for the teachers to share and discuss teaching difficulties or issues they face with other teachers for solutions. Topics that are commonly discussed are learning methods and strategies, problems or issues related to students, and the use of environment-based educational facilities. In addition, teachers are also encouraged to be still involved in KKG after the other workshops that are periodically conducted every three months. A principal said this:

I encourage teachers to be active in KKG. It is a place where they can discuss the problems faced in class. Also, their communication skills can be improved, they are trained to discuss and argue. This is important. (WR-051)

In line with the above statement, a principal stated this:

My teachers are required to take part in the local area KKG which is routinely held once a week. Their participation can help improve their insight and knowledge. (WR-052)

This situation indicates that principals feel the need to develop teachers' professionalism continuously.

\section{DISCUSSION}

The results show a variety of school leadership strategies to improve public elementary teachers' professionalism. The strategies are providing exemplary behavior and attitude, fostering work discipline, motivating teachers, providing educational supervision, and continuously developing teacher professionalism.

\subsection{Providing exemplary behavior and attitudes}

The principals show exemplary behaviors and attitudes to all parties in school, including the teachers. Exemplary behaviors emphasize time discipline, which includes coming early to schools. Meanwhile, the exemplary attitudes include being persistent, humble, 
responsible, noble, obedient to the rules, patient, friendly, fair, wise, and firm. The teachers also need to possess a high work ethic. It is hoped that teachers will emulate the attitude exemplified by the school principals.

What the principal has done is similar to what was stated by Daryanto (2008: 108) that the principals should become a "perfect" figure, and by Ambarita (2015) that principals should be able to be exemplary leaders. This is important since it influences teacher professionalism. According to Ainurrofiq (2010: 65), characteristics of professional teachers are obeying the law, guiding students (being patient, consistent, fair and open, caring for students, and democratic), obedient to the leaders, devoted to the job, and maintaining good relationships with colleagues. So, principals, for example, should be able to make teachers discipline in terms of time. Those are coming to school on time show commitment as professional teachers with good attitudes to improve their quality.

\subsection{Fostering work discipline}

Fostering work discipline carried out by the principals includes fostering teachers to be discipline in administrative work. The administrative work includes the development of lesson plan, Semester Program (SP), Annual Program (AP), and syllabus. In competing for this kind of work, the principals should ask the teachers to minimize mistakes and assist those who do not understand the tasks. This is in line with Mulyasa (2006: 122) stating that school principals as administrators should work on administrative management activities. Also, as a leader, they need to provide support and assistance to teachers who need help with their works, either individually or collectively (Harris, 2010).

The principals are assertive in fostering teachers' discipline. They remind teachers always to be orderly and obey the rules being set, to arrive at schools on time (earlier than the office hour) and not to leave their teaching hours for specific reasons by not permitting teachers to leave class or school during working hours. This decisive leadership action is shown by most of the principals. What principals did, as Sobri, et al. (2009) said, can develop teachers' professionalism. 


\subsection{Motivating teachers to work professionally}

The principals motivate the teacher by instilling religious values, for example, by conveying that teaching is part of religious observance. When there is a teacher who feels a lack of enthusiasm and seems less passionate about working, the school principals try to remind them about this value. This belief encourages teachers to teach well, so this kind of encouragement is needed. In addition, the principals motivate teachers by conduct a briefing every morning. This kind of briefings is carried out before classes begin and after the principals welcome the students. In briefings, the principals encourage the teachers to work well.

The findings are in line with Sobri, et al. (2009). He said that motivating teachers can be fostered through discipline and encouragement, which is, in this case, using religious values and briefing. As being motivated, it is expected that teachers are fully aware of their responsibilities and willingly, professionally, carry out their duties (Ambarita, 2015).

\subsection{Providing educational supervision}

Supervision is a planned activity to help teachers and educational personnel to work effectively and efficiently. It does not merely mean observing whether teachers work well in accordance with the instruction and provisions set. It should also develop the teacher's ability to teach. The results of this study show that principals supervise the learning process by visiting the classroom, observing, mentoring, as well as providing both individual and informal guidance.

The principal's actions are in line with Purwanto (2014) and Muslim (2010), who state that educational supervision is essential for the development of teacher professionalism. Supervision techniques performed by the principals might vary and need modification, considering the context where it takes place (Purwanto, 2014; Sagala, 2010). Concerning mentoring techniques, Saud (2009: 103) states that this technique is good to create cooperation with colleagues. This is very beneficial for developing teacher's professionalism. Many problems can be solved if teacher collaboration is in place. 


\subsection{Encouraging teachers to participate in continuing professional development programs}

Professionalism is a mental attitude shown by the commitment of people with the same professions always to actualize and improve their professional quality. A teacher who has high professionalism will show a mental attitude and commitment to realize and improve professionalism through various ways and strategies. Teachers always develop themselves in accordance with the demands of the times so that their existence always gives a professional meaning. Therefore, teacher professionalism requires continuous professional development.

The results of this study show that principals encourage teachers to develop their professionalism continuously. Teachers were encouraged to join workshops, seminars, and KKG. This idea is supported by Aedi (2014) stating that seminars, workshops, training, and being active in KKG programs can help improve teacher's professionalism. Through these programs, teachers' competencies can increase. Moreover, they are trained to be better in communicating, working in teams, and leading a discussion.

\section{CONCLUSION}

Teacher professionalism is one of the factors that can be developed in various ways to success. The results of this research show that several leadership strategies can be implemented by school principals to develop teacher professionalism. The strategies are providing exemplary behavior and attitude, fostering work discipline, motivating teachers, providing educational supervision, and encouraging teachers to develop their professionalism continuously. This study implies that principals need to use a wide range of strategies to improve teacher professionalism effectively.

\section{Acknowledgement}

This research received no specific grant from any funding agency in the public, commercial, or not-for profit sectors.

\section{REFERENCES}

Aedi, N. (2014). Pengawasan pendidikan. Tinjauan teori dan praktek. Jakarta: Rajawali Press.

Ainurrofiq. (2010). Kiat menjadi guru profesional. Jogjakarta: Ar-Ruzz Media. 
Ambarita, A. (2015). Kepemimpinan kepala sekolah. Yogyakarta: Graha Ilmu.

Benzies, K. M., \& Allen, M. N. (2001). Symbolic interactionism as a theoretical perspective for multiple method research. Journal of Advanced Nursing, 33(4), 541-547. doi: 10.1046/j.1365-2648.2001.01680.x

Collins, J. (2001). Good to great: Why some companies make the leap and others don't. New York: Harper Collins.

Daryanto. (2008). Administrasi pendidikan. Jakarta: Rineka Cipta.

Dharma, S. (2005). Manajemen kinerja. Yogyakarta: Pustaka Pelajar.

Fathurrohman. (2012). Belajar dan pembelajaran meningkatkan mutu pembelajaran sesuai standar nasional. Yogyakarta: Teras.

Harris, A. (2010). Effective leadership in challenging schools. In P. Peterson, E. Baker, \& B. McGaw (Eds.), International Encyclopedia of Education (3rd ed., pp. 777782). London: Elsevier, Ltd.

Jacobson, S. (2011). Leadership effects on student achievement and sustained school success. International Journal of Educational Management, 25(1), 33-44. doi:10.1108/09513541111100107

Karadag , E., Bektas, F., C, og altay, N., Yalc,ın., M. (2015). The effect of educational leadership on students' achievement: a meta-analysis study. Asia Pacific Educ. Rev. 16, 79-93. doi: 10.1007/s12564-015-9357-x

Leithwood, K., Harris, A., \& Hopkins, D. (2008). Seven strong claims about successful school leadership. School Leadership \& Management: Formerly School Organization, 28(1), 22-42. doi:10.1080/13632430701800060

Leithwood, K., \& Riehl, C. (2005). What do we already know about educational leadership? In W.A. Firestone \& C. Riehl (Eds.), A new agenda for research in educational leadership (pp. 12-27). New York: Teachers College Press.

Memprihatinkan, potret pendidikan. (2018, May 2). Kompasiana. Retrieved from https://www.kompasiana.com/syarif1970/5ae933c4caf7db6e6f784102/memprih atinkan-potret-pendidikan-indonesia-zaman-now

Marno. (2012). Strategi dan metode pengajaran (menciptakan keterampilan mengajar yang efektif dan edukatif). Yogyakarta: Ar-Ruzz Media.

Mulyasa, E. (2006). Menjadi kepala sekolah profesional. Bandung: PT Remaja Rosdakarya.

Mudlofir, A. (2013). Pendidik profesional. Jakarta : Raja Grafindo Persada.

Nurfuadi. (2012). Profesionalisme guru. Purwokerto: STAIN Press.

O'Donoghue, T. (2007). Planning your qualitative research project. An introduction to interpretive research in education. London: Routledge.

Purwanto, N. (2014). Administrasi dan supervisi pendidikan. Bandung: Rosdakarya.

Sagala. (2010). Supervisi pembelajaran dalam profesi pendidikan. Bandung: Alfabeta.

Saud. (2009). Pengembangan profesi guru. Bandung: Alfabeta.

Siswoyo. D. (2013). Ilmu pendidikan. Yogyakarta: UNY Press.

Sobri, Jihad, A., Rochman, C., Pr. (2009). Pengelolaan pendidikan. Yogyakarta: Multi Pressindo.

Suparmin. (2015). Profesi kependidikan. Sukoharjo: Fataba Press.

Suyanto. (2013). Menjadi guru profesional: strategi meningkatkan kualifikasi dan kualitas guru di era global. Jakarta: Erlangga.

Sugiyono. (2015). Metode penelitian pendidikan: pendekatan kuantitatif, kualitatif dan $R \& D$. Bandung: Alfabeta. 
Sun, J., \& Leithwood, K. (2015) Direction-setting school leadership practices: a metaanalytical review of evidence about their influence, School Effectiveness and School Improvement, 26 (4), 499-523.

Usman. (2002). Menjadi guru profesional. Bandung: PT. Remaja Rosdakarya.

Ylimaki, R. M., Jacobson, S. L., \& Drysdale, L. (2008). Making difference in challenging high poverty schools: Successful principals in the USA, England, and Australia. School Effectiveness and School Improvement: An International Journal of Research, Policy and Practice, 18(4), 361-381. doi:10.1080/09243450701712486 